\title{
A SURVEY OF POTENTIAL DREDGE DISPOSAL SITES IN THE TIDAL POTOMAC RIVER AND UPPER POTOMAC ESTUARY BETWEEN WASHINGTON, D.C. AND THE ROUTE 301 BRIDGE
}

By Nancy B. Rybicki, Henry A. Ruhl, Justin T. Reel, and Virginia Carter

\section{US Geological Survey}

Open-File Report 99-234

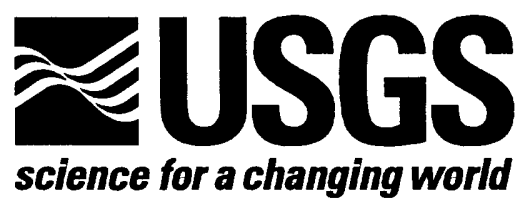

Reston, Virginia 


\title{
U. S. DEPARTMENT OF THE INTERIOR BRUCE BABBITT, Secretary
}

\author{
U. S. GEOLOGICAL SURVEY \\ Charles G. Groat, Director
}

For additional information, write to:

Chief, Vegetation and Hydrogeomorphic Relations

U. S. Geological Survey

National Center, MS 430

Reston, Virginia 20192
Copies of this report may be purchased from:

U. S. Geological Survey

Branch of Information Services

Box 25286, Federal Center

Denver, Colorado 80225 


\section{CONTENTS}

$\begin{array}{lc} & \text { Page } \\ \text { Abstract } & 1 \\ \text { Introduction } & 1 \\ \text { Study methods } & 1 \\ \text { Potential dredge disposal sites } \quad & 2 \\ \quad \text { Shallow-water disposal sites } \quad & 2 \\ \text { Deep-water disposal sites } & 4 \\ \text { Land disposal sites } & 4 \\ \text { Discussion } & 4 \\ \text { References cited } & 5\end{array}$

\section{ILLUSTRATIONS}

Figures 1-3. Maps showing the location of proposed dredge and

potential dredge spoil disposal sites in the tidal Potomac River and upper Potomac Estuary

Figure 1. Washington, D.C. to Broad Creek

Figure 2. Swan Creek to Chicamuxen Creek

Figure 3. Quantico, Va. to the Route 301 Bridge

\section{TABLES}

Table 1. Potential dredge disposal sites for the Potomac River between Washington, D.C. and the Route 301 Bridge 


\title{
A SURVEY OF POTENTIAL DREDGE DISPOSAL SITES IN THE TIDAL POTOMAC RIVER AND UPPER POTOMAC ESTUARY BETWEEN WASHINGTON, D.C. AND THE ROUTE 301 BRIDGE
}

\author{
By Nancy B. Rybicki, Henry A. Ruhl, Justin T. Reel and Virginia Carter
}

\section{Abstract}

Several potential sites for the disposal of material dredged from the tidal Potomac River are identified. Five land sites, seven shallow-water sites, and four deep-water sites are identified. The shallow-water sites are further identified as being suitable for placement of the dredge material to create wetlands, create or restore islands, or nourish beaches.

\section{Introduction}

Disposal sites are needed for material dredged from the main channel of the Potomac River (figs. 1-3). The dredged material may be placed on land or in deep or shallow water, and may be used to create wetlands, create or restore islands, or nourish beaches. Various dredge material disposal techniques are described in a number of publications (Environmental Laboratory, 1978; U.S. Army Corp of Engineers, 1987; Gill and others, 1995). Data on topography, bathymetry, bottom substrate, and the distribution and abundance of submersed aquatic vegetation (SAV) were used to determine the suitability of several potential sites for the disposal of material dredged from the Potomac River. Those sites are identified in this report. The final selection of sites for disposal, however, will be made by the U.S. Army Corps of Engineers (COE) after further testing, planning, authorization, and review (U.S. Army Corps of Engineers, 1987).

\section{Study Methods}

Dredge disposal sites were identified in the field during the course of the U. S. Geological Survey (USGS) annual shoreline SAV survey (Ruhl and others, 1999) and by reviewing existing aerial photos and topographic maps. The potential disposal sites identified here met the following criteria (Environmental Laboratory, 1978):

- Capacity to meet disposal needs

- Proximity to dredging projects

- Topography and bathymetry 
- Environmental and social acceptability

- Tidal and flow conditions

- Beneficial use

Shallow water sites were considered if they were approximately 8.1 hectares (20 acres) in size, were historical wetlands or islands that could be restored, and had a shallow slope and hard bottom. Slope and substrate characteristics were determined by site inspection and reference to bottom substrate type and water-depth information collected at 143 transects located in the in the Potomac River from Washington, D.C. to the Route 301 Bridge (Paschal and others, 1982). Potential shallow-water sites exhibited signs of shoreline erosion and the need for shoreline protection. Land disposal sites were considered if they were large public properties, potential construction sites, or gravel pits. Deep-water disposal sites were considered on the basis of water depth as reported on National Oceanographic and Atmospheric Administration (NOAA) navigation charts.

\section{Potential Dredge Disposal Sites}

Seven shallow-water, five land, and four deep-water disposal sites were identified (table 1 and figs. 1-3). Specific techniques or possible approaches for dredge material disposal are suggested for each shallow site. These approaches include wetland restoration, island restoration including a tidal marsh lagoon, breakwater or wetland creation, and beach nourishment. Occurrence of SAV is also reported at each site. Sites where SAV was present historically were rarely considered as potential dredge disposal sites because SAV is protected by law and provides a beneficial use. In general, when an area is already considered to be providing ecological benefit, state or fish and wildlife resource managers do not recommend substitution of an alternative beneficial use of the site. Despite this, several sites with SAV present were included in order to provide a more comprehensive list.

\section{Shallow Water Disposal Sites}

Seven shallow water disposal sites were identified (table 1). The Kenilworth Aquatic Gardens (or Kingman Island areas (SS-1, fig. 1, table 1) are located in the Anacostia River where current restoration projects could be expanded. The Kenilworth Marsh Restoration Project, which restored 13 hectares (32 acres) of marsh, was part of the COE, Baltimore District's plan to restore 32 hectares (79 acres) of tidal and non-tidal wetland habitat in the Anacostia River. Several research projects in this area are evaluating the wetland restoration that has already taken place at Kenilworth Aquatic Gardens and determining the beneficial use of barren mud flats in the Anacostia. This site is suitable for dredge disposal because historical maps show that extensive wetlands were present here, past restoration projects were successful, and the 
area was targeted by the Virginia Power Company for future wetland restoration projects (Peter May, D C Government, oral communication, 1997).

Goose Island (SS-2, fig. 1) in the Potomac River near Alexandria, Va. and Craney Island (SS-3, fig. 2), offshore of Mason Neck Wildlife Refuge, are two potential sites for island restoration. Goose Island had several trees on it in 1978 , but the island has since eroded away. The shoal in the location of Goose Island was vegetated with Hydrilla verticillata and Myriophyllum spicatum in 1997, whereas the shoal surrounding Craney Island has never been vegetated with SAV, possibly because of poor water clarity or lack of propagules. Craney Island originated as an industrial fill disposal site, and in 1997, the island supported several live trees (U. S. Army Corps of Engineers, 1987, p. C-4). Either of these two islands could be enlarged with dredge material, although Craney Island would be more suitable than Goose Island because it lacks historical SAV. Flood velocities, which could cause scouring of any site, are more likely to be lower at Craney Island than at Goose Island because of the increased width of the river at Craney Island.

Site SS-4 is located just offshore of the eroding shoreline of Potomac Shoreline Park (fig. 2). This entire shoreline was suggested as a site for the construction of a combination breakwater structure and wetland (Gill and others, 1995). On the east side of High Point, there is a cove at the mouth of a marsh creek. This cove has a hard sandy and shallow bottom. The north side of High Point is lined with trees, and there is evidence that the shoreline is eroding and trees are continually falling into the river. SAV has never been reported along Potomac Shoreline Park between Sandy Point and High Point, or between High Point and the private boat dock (fig. 2). There is a wildlife sanctuary along this shoreline as well as breakwater structure. Wetland creation would enlarge this habitat while protecting the shoreline from erosion, as was done on the Chesapeake Bay (Gill and others, 1995). The area may be unsuitable for dredge disposal if the wildlife is considered too sensitive for this activity.

Two wetland sites, one north of Neabsco Creek at Farm Creek (SS-5, fig. 2) and the other at Brent Marsh (SS-6, fig. 3) are also potential sites for either wetland restoration or a combination of breakwater structure and wetland restoration. Marsh-vegetation root masses were noted just offshore of the wetland, which suggests that these marshes are losing acreage. Both marshes adjoin a wide, shallow shelf where dredge material could be deposited in a marsh restoration project. Farm Creek marsh has never had SAV along its shoreline.

Dyke Marsh in Alexandria, Va. is another possible marsh restoration site. The National Park Service (NPS) manages Dyke Marsh and has noticed erosion of the marsh over the last few years (Greg Marsh, NPS, oral communication, 1997). The marsh was used as a building-debris fill site in the 1960's. The Haul Road Trail leads to the old dredge disposal site $(6.9$ hectares [17 acres]) that is now part of the tidal marsh (U. S. Army Corps of Engineers, 1987, p. C-4). A large part of Dyke Marsh's original acreage was previously dredged for sand and gravel (Ed Risely, Friends of Dyke Marsh, written communication, 1997). As a result of the previous dredging activity, the area just south of the Belle Haven 
Marina at the northern end of the marsh has a steep gradient. This site was previously vegetated with Hydrilla verticillata. Because of the steep gradient along a large part of the marsh and the previous occurrence of SAV, this site may not meet the COE requirements.

A public beach nourishment site is proposed at the mouth of Aquia Creek at Aquia Landing Park (SS-7, fig. 3). This is a Stafford County park that is open only during the summer for swimming. The park is located at the end of Brook Road (Route 608). The site has the advantage of being one of the few potential dredge disposal sites identified in the vicinity of the Maryland Point dredge sites. The disadvantages of this site are that Aquia Landing beachfront is fairly small, and SAV has been recorded growing adjacent to this site. Leesylvania Park is another park, which has public beach access (LS-3, fig. 2), but does not allow swimming. There is also SAV in this area. Below the Route 301 Bridge are two additional public beaches where beach nourishment could be considered: Westmoreland State Park, Va. and Colonial Beach, Va.

\section{Deep-Water Disposal Sites}

Four deep-water sites were identified for placement of dredge material (table 1). Three of the four deep-water disposal sites are located between Alexandria and Quantico, VA (DS-1, 2, 3, fig. 2). The fourth deep-water disposal site (DS-4, fig. 3) is located near the 301 Bridge at Mathias Point. These sites range from 15 to $36 \mathrm{~m}$ in depth.

\section{Land-Disposal Sites}

Five land-disposal sites were identified (table 1). Dredge material could be used on the potential land disposal sites for erosion gully fill, topographic relief, and gravel pit fill material. These potential land sites provide large areas where material could be deposited nearshore and later repositioned on the properties for fill, dikes, parking lots, or roads. Fort Belvoir (LS-1, fig. 2) is the land disposal site located farthest north in Lorton, VA, and has deep water and riverside road access at two sites in Gunston Cove. Occoquan Bay National Wildlife Refuge (the old Harry Diamond Laboratory) (LS-2, fig. 2) also has deep water and riverside road accessibility at Deephole Point. A part of this property is wetland, which at one time probably extended farther into Occoquan Bay. A project could be considered that would enlarge the existing wetland into the Bay.

The third land disposal site, Leesylvania State Park (LS-3, fig. 2), is in Dumfries, Va. off of Neabsco Creek Road. The park is mostly forested and has a large parking area adjacent to the boat ramps. The fourth and fifth land disposal sites were Chapmans Landing (LS-4, fig. 2) and Maryland Rock Industries, Inc. sand and gravel operation (LS-5, fig. 3). These sites are in Maryland, near Indian Head. Maryland Rock Industries, Inc. is an operating sand and gravel business along the Potomac below Chicamuxen Creek. Managers of any of these five sites may be willing to receive dredge disposal material and put it to a beneficial use. 


\section{Discussion}

A number of potential disposal sites have been identified in this report. Land and deep-water placement of dredge material are viable alternatives, but do not provide the beneficial aquatic habitat that shallow site placement provides. The impact of deep-water placement of dredge material may be sitespecific potential effects, and testing and evaluations of specific sites is suggested. Potential effects of dredge disposal in deep water or shallow water include resuspension and erosion of sediments after placement, and disturbance of existing SAV, fish, and benthic communities. In addition, the grain size and toxicity of the dredge material are critical factors in determining what type of action could be taken with the dredge material.

From our shoreline survey, Craney Island appears to provide the most advantages. The site is large enough to meet disposal needs, is centrally located to many of the dredge channels, has not had SAV during any USGS SAV survey, was of adequate depth and slope for island restoration, and was situated downstream of the most congested boating areas. Craney Island is far enough downstream that scour from flood velocities is more dissipated than at sites closer to the Fall Line. The site is large enough that the island restoration could include an upland and aquatic habitat. The aquatic habitat could be a tidal marsh-lagoon system that would provide a harbor for potential SAV. The upland could provide a valuable waterbird-nesting habitat because it is a sufficient distance from shore to prevent the establishment of mammalian predators (Erwin and Hatfield, 1995). The other sites also meet many of the COE requirements to dispose of the dredge material efficiently and, if possible, to create a beneficial use of the material.

A variety of concerns make it difficult to determine a suitable disposal site. Wetland restoration and creation would provide the benefit of increasing the quantity of wetland habitat in the Potomac River watershed. Shore protection would protect valuable habitat and prevent bank erosion. Beach nourishment would improve the recreational value of the site. Conversely, beach nourishment, deep-water placement, wetland restoration and creation, and island restoration may negatively impact existing fish and benthic communities that already provide a beneficial use of the river bottom. Land disposal would be the most beneficial use if none of the other alternative sites could be agreed upon and unaltered shallow sites are determined to provide the best beneficial use. Deep-water placement would probably be the least controversial approach in cases where shallow-water and land sites are not feasible. All sites identified here are preliminary suggestions and will require study of wildlife sensitivity and physical constraints (wave energy, scour sites, currents, etc.) to determine site suitability for dredge disposal. 


\section{References Cited}

Environmental Laboratory, 1978, Wetland habitat development with dredged material: Engineering and plant propagation: Technical Report DS-78-16, U.S. Army Corps of Engineers Waterway Experiment Station, Vicksburg, Miss.

Erwin, M. R., Hatfield, J. S., and Williams, J. T., 1995, The value and vulnerability of small estuarine islands for conserving metapopulations of breeding waterbirds, Biol. Conserv., vol. 71, pp. 187-191.

Gill, J. W., McGowan, P., and Gerlich, L. E., 1995, Monitoring study, Eastern Neck Island National Wildlife Refuge: Wetland Research Program Technical Report WRP-RE-12.

Paschal, J. E., Jr., Miller, D. R., Bartow, N. C., and Carter, Virginia, 1982, Submersed aquatic vegetation in the tidal Potomac River and Estuary of Maryland, Virginia, and the District of Columbia, Hydrologic data report, May 1978 to November 1981: U.S. Geological Survey Open-File Report 82-694, 220.p.

Ruhl, H. A., Rybicki, N. B., Reel, J. T., and Carter, Virginia, 1999, Submersed aquatic vegetation and $H y d r i l l a$ verticillata distribution and abundance for the tidal Potomac River and upper Potomac Estuary, Maryland, Virginia, and The District of Columbia, 1993-1998, U.S. Geological Survey Open File Report-99-233.

U.S. Army Corps of Engineers, 1987, Beneficial use of dredge material, Engineer Manual, EM 1110-2-5026. 


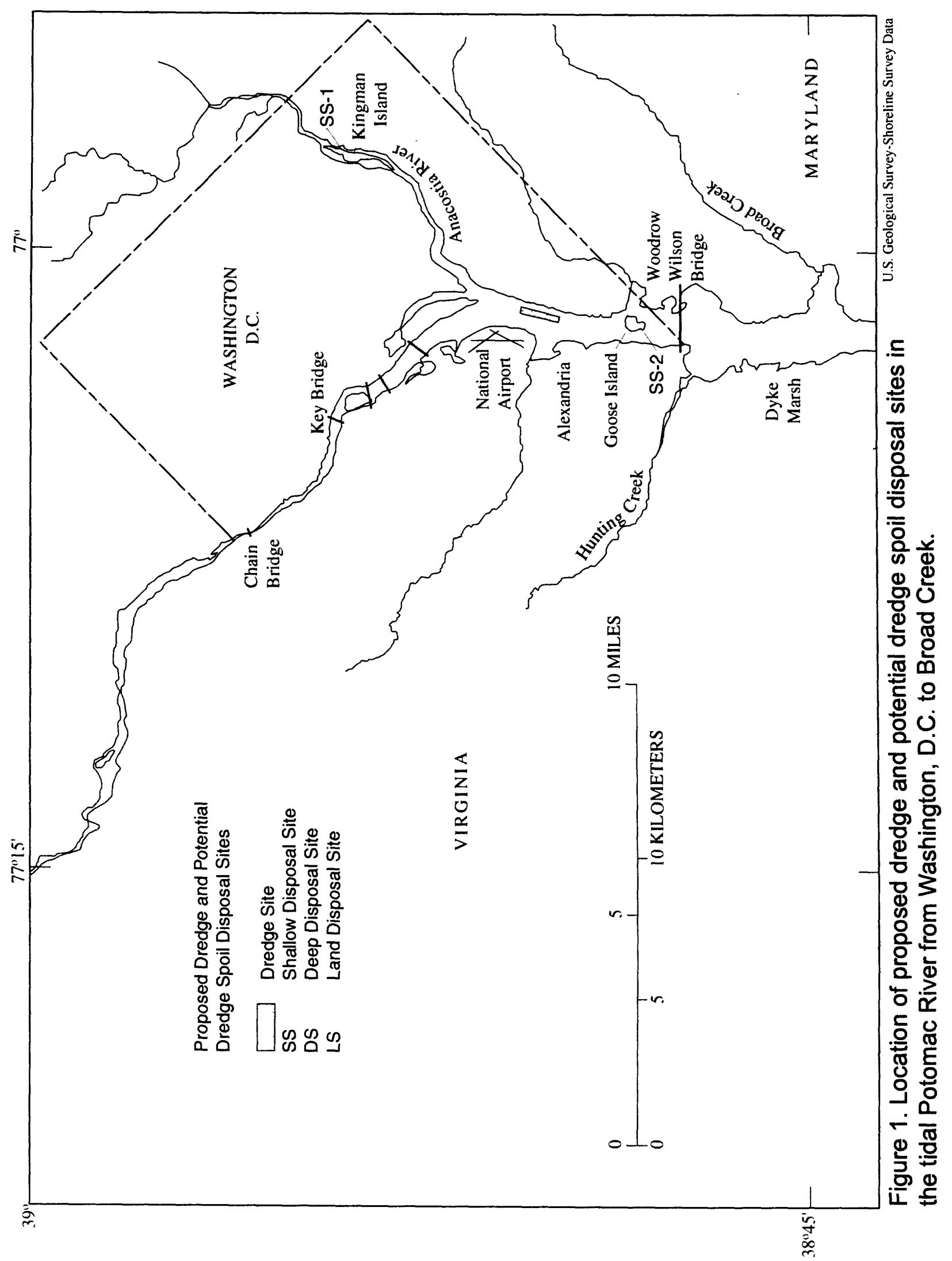




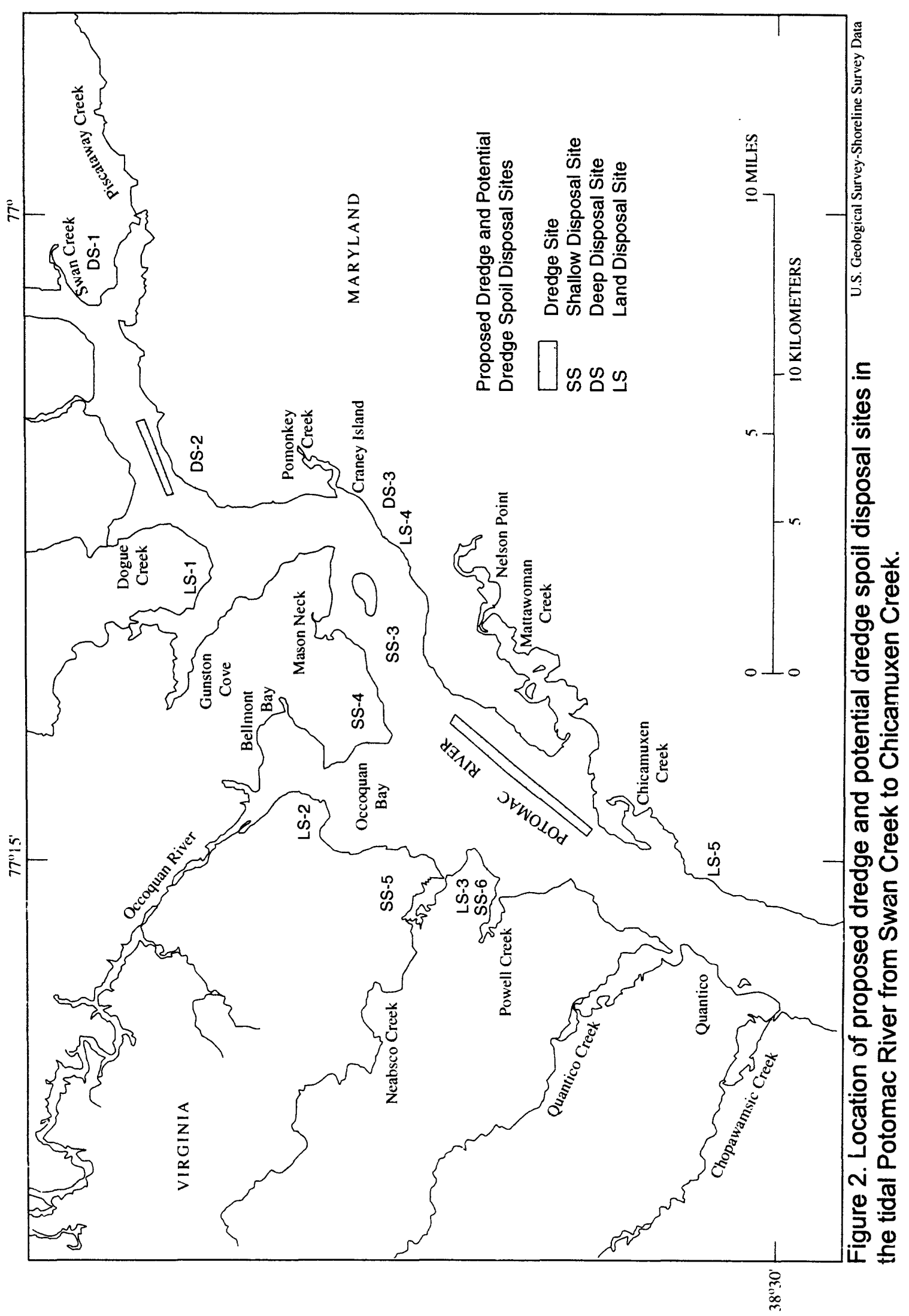




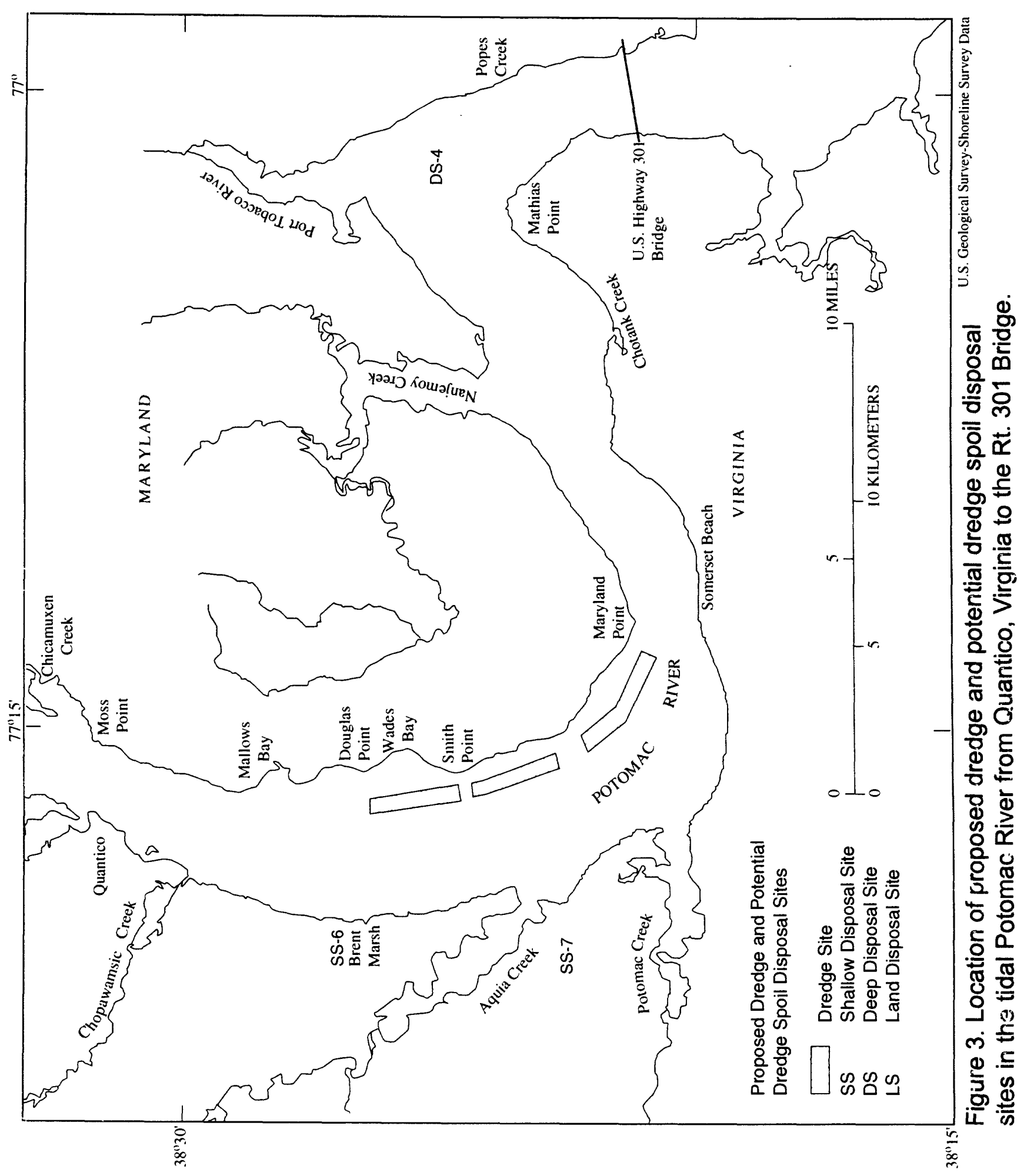


Table 1. Proposed dredge disposal sites for the Potomac River between Washington, D.C. and the Route 301 Bridge [No SAV means no submersed aquatic vegetation (SAV) reported at the site in any past shoreline survey. All other shallow sites were vegetated historically (1983-1997).]

\section{Shallow-water disposal sites (SS)}

SS-1. Kenilworth Aquatic Gardens or Kingman Island area in the Anacostia River (no SAV)

SS-2. Goose Island

SS-3. Craney Island, offshore of Mason Neck National Wildlife Refuge (no SAV)

SS-4. In Occoquan Bay, at High Point, Potomac Shoreline Park (no SAV)

SS-5. North of Neabsco Creek along eroding marsh at Farm Creek, Maramusco National Wildlife Refuge (no SAV)

SS-6. Brent Marsh

SS-7. Aquia Landing Park

Land-disposal sites (LS)

LS-1. Fort Belvoir Army Base

LS-2. Occoquan Bay National Wildlife Refuge

LS-3. Leesylvania State Park

LS-4. Chapman's Landing

LS-5. Maryland Rock Ind. Inc. sand and gravel operation

\section{Deep-water disposal sites (DS)}

DS-1. Channel marker " 80 " at Fort Washington (depth is 53 feet on navigation chart)

DS-2. Channel marker " 66 " north of Gunston Cove (depth is 70 feet on navigation chart)

DS-3. Channel marker " 55 " north of Indian Head (depth is 50 feet on navigation chart)

DS-4. Channel marker "6" at Mathias Point, Md. (depth is 119 feet on navigation chart) 